\title{
The Incorporation Problem in Interdisciplinary Legal Research
}

\author{
Some Conceptual Issues and a Practical Illustration
}

Theunis Robert Roux*

\begin{abstract}
The seriousness of the incorporation problem in interdisciplinary legal research, this article argues, depends on how legal research is understood. If legal research is understood as a single, inherently interdisciplinary discipline, the problem largely falls away. On this view, the incorporation of other disciplines into legal research is what legal academics have for the last 40 years already successfully been doing. If, on the other hand, legal research is best conceived as a multi-disciplinary field, consisting of a core discipline - doctrinal research - and various other types of mono-disciplinary and interdisciplinary research, the incorporation of other disciplines presents real difficulties. For legal academics engaged in socio-legal research, in particular, two problems arise: the practical problem of trying to address a legal professional and academic audience at the same time and the philosophical problem of trying to integrate the internal perspective of doctrinal research with the external perspective of other disciplines. In the final part of the article, these practical and philosophical difficulties are illustrated by reference to the author's research on the politics of judicial review in new democracies.
\end{abstract}

Keywords: legal research, doctrinal research, interdisciplinary, incorporation problem, comparative constitutional law

\section{Introduction}

Can the conceptual frameworks and methods of other disciplines be incorporated into the discipline of law? Yes, absolutely, or no, definitely not. It all depends on how the discipline of law is understood and, indeed, on whether there is such a thing as 'the discipline of law' at all. If law is understood as a single, inherently interdisciplinary discipline that has been progressively expanding over the last 40 years to encompass a wide variety of types of research, ${ }^{1}$ incorporation does not really present a problem. On this view, incorporating the conceptual frameworks and methods of other disciplines is what

* Theunis Robert Roux is Professor of Law at the University of New South Wales, Australia.

1. See, for example, A. Bradney, 'Law as a Parasitic Discipline', 25 Journal of Law \& Society 71 (1998). legal academics have already been doing: taking bits from this discipline here, pieces from that discipline there, and using those bits and pieces to deepen our understanding of law's role in society. To be sure, legal academics have exposed themselves in this way to the charge of interdisciplinary dilettantism - of having become academic dabblers with no real conceptual frameworks and methods of their own. This charge can be met, however, by improving the rigour with which other disciplines are used, and by emphasising legal academics' continuing connection to the legal profession.

If, on the other hand, we understand the research that legal academics have been doing as belonging, not to a single discipline, but to a variety of disciplines and interdisciplines, everything changes. For then, legal research is best conceived as a multidisciplinary field consisting of a core discipline - doctrinal research - and two other main types of research: (i) interdisciplinary research that combines doctrinal research and the conceptual frameworks and methods of one or more other disciplines and (ii) research about law and legal institutions that has no doctrinal component. On this understanding, incorporation does present something of a problem, at least for legal academics who are interested in the first of these two other main types of legal research, or what is commonly called 'socio-legal research'. For these academics, one of two things is at risk of happening: either the conceptual frameworks and methods of the other disciplines on which they are drawing might become distorted under the pressure of doctrinal incorporation or the reverse might occur - the doctrinal part of their research might become subsumed under the non-doctrinal part, to the point where their research ceases to be of much value to the legal profession, whatever wider scholarly value it may have.

The rest of this article sets out the thinking behind this conception of the incorporation problem. The next section addresses the disciplinary question. While legal academics have always drawn on other disciplines, it is argued, it is wrong to conclude from this that legal research is an inherently interdisciplinary discipline. Doctrinal research, for its part, is best understood as research that is directed at the construction of legal doctrine in a particular legal system. Such research characteristically draws on other disciplines to improve the rational coherence and social efficacy of law. Provided 
doctrinal researchers respect the conventionally accepted reasoning techniques of the legal tradition in which they are working, there is no reason why such research should be regarded as interdisciplinary. It follows that legal research as a whole is best conceived as a multidisciplinary field in which doctrinal research is but one of many mono-disciplinary and interdisciplinary forms of research being pursued.

The paper then moves on to consider the incorporation problem when legal research is understood in this way. The problem does not really concern doctrinal researchers, it is argued, because their use of other disciplines by definition occurs on law's terms, meaning that the methodological standard they need to observe is an entirely internal doctrinal standard. Rather, the problem affects those who are engaged in the particular kind of socio-legal research that legal academics do: research that attempts to integrate the internal doctrinal perspective of the trained lawyer with the external perspective of one or more other disciplines. For these researchers, the incorporation problem is partly a practical problem of belonging - of being forced to choose between two audiences: the legal-professional community and the wider academic community. It is also partly a philosophical problem in as much as it raises the question, common to all interdisciplinary research, of whether it is possible to participate in two different practices at the same time.

The final section of the article illustrates this understanding of the incorporation problem by referring to my own research area: the politics of judicial review. Like many other legal academics, I became frustrated fairly early on in my career with a purely doctrinal approach. I wanted not just to participate in the construction of constitutional law doctrine from an internal, legal-professional perspective but also to place the work of the court whose jurisprudence I was studying - the South African Constitutional Court - into a broader, comparative perspective. That interest led me to begin reading political science accounts of judicial decisionmaking in the United States. I found those accounts fascinating because they were so dismissive of the perspective that I had taken for granted: that law is capable of constraining judicial decision-making in a way that sets it apart from politics. After 15 years of research in this area, I think I may have found a way of integrating my specifically South African understanding of the constraining influence of law with an American political science understanding of constitutional courts as deeply implicated in politics. Not just that, but I think that the interdisciplinary conceptual framework I have developed is capable of delivering insights that each of these disciplines on its own is not. I should be happy with that, but I am plagued by a concern that I have lost both my potential audiences along the way - that my work is now not doctrinal enough to be of much interest to South African (or even comparative) constitutional lawyers and insufficiently sophisticated from a methodological point of view to be of much interest to political scientists.

\section{Defining Law as a Discipline}

As Sanne Taekema has argued: 'Interdisciplinarity does not make sense without the idea of disciplinarity. To say anything sensible about interdisciplinary research into law, it is therefore necessary to have an idea of what the discipline of law is'. ${ }^{2}$ This is clearly correct. The nature of law as an academic discipline, however, is contested, and the severity of the incorporation problem differs accordingly.

In the editors' introduction to this special issue, Kathleen Sullivan's 2002 Michigan Lam Reviem foreword is cited in support of the proposition that 'legal doctrinal research cannot be other than interdisciplinary by nature'. ${ }^{3}$ It is not clear, however, that this is what Sullivan was arguing. Her actual claim is that 'the discipline of law is itself multidisciplinary, built upon if not reducible into elements of the humanities and social sciences'. ${ }^{4}$ That claim seems to be addressing legal research as a whole rather than doctrinal research in particular. Be that as it may, the idea that any discipline may be inherently interdisciplinary is controversial. ${ }^{5}$ To be sure, many new disciplines do arise from the combination of two or more disciplines - like biochemistry, for example, which has its origins in the separate disciplines of biology and chemistry. But it is a defining quality of a discipline that it must possess its own distinctive conceptual frameworks and methodologies. ${ }^{6}$ However much it draws on existing disciplines, if a form of academic research is to be recognised as a discipline in its own right, it must transcend the disciplines on which it is drawing to create some larger whole. Disciplines on this view of things may have interdisciplinary origins, but it is conceptually impossible for there to be such a thing as an interdisciplinary discipline.

This position may come across as a little dogmatic. Definitions of the term 'discipline' are largely a matter of taste, and some scholars might prefer to define disciplines so as to leave space for the notion of an interdisciplinary discipline. I thus have no desire to defend the above conception as the 'correct' one. There madness (and great deal of fatuousness, too) lies. In relation to the editors' specific claim that 'legal doctrinal research cannot be other than interdisciplinary by nature', how-

2. S. Taekema, 'Relative Autonomy: A Characterization of the Discipline of Law', in B. van Klink and S. Taekeman (eds.), Law and Method (2011) 33.

3. See Editors' introduction to this special issue.

4. K.M. Sullivan, 'Foreword: Interdisciplinarity', 100 Michigan Law Review 1217, at 1218-1219 (2002).

5. I can understand (although I do not completely agree with) the claim that socio-legal research is inherently interdisciplinary, for there one is talking about a field to which a number of researchers are contributing, either from within their different disciplines (making the field strictly speaking multidisciplinary) or by combining two or more of those disciplines (interdisciplinary research proper). But to say that a single discipline is inherently interdisciplinary challenges conventional notions of what a discipline is.

6. S. Taekema and B. van Klink, 'On the Border: Limits and Possibilities of Interdisciplinary Research', in B. van Klink and S. Taekema (eds.), Law and Method (2011) 7 
ever, I do have a bit of an axe to grind - or three to be precise. Firstly, I think that this claim gets the essence of doctrinal research wrong. At the very least, the alternative possibility - that doctrinal research, in drawing on other disciplines, simply absorbs them into its own logic - needs to be properly considered. Secondly, the proposition that doctrinal research is inherently interdisciplinary needs to be carefully distinguished from the proposition that legal research is today characteristically interdisciplinary. That alternative proposition seems to me more defensible - not because legal research is an exception to the rule that disciplines may not be inherently interdisciplinary but because legal research is not a discipline, but rather a convenient, catch-all term for the research that legal academics do. Thirdly, the claim that doctrinal research is inherently interdisciplinary makes it hard to understand the particular kind of interdisciplinary research that legal academics do, which combines doctrinal research with research that draws on the conceptual frameworks and methods of other disciplines. If doctrinal research is inherently interdisciplinary, what is the difference between that form of research and socio-legal research? The rest of this section grinds each of these axes in turn.

Consider first my worry about the editors' claim that 'legal doctrinal research cannot be other than interdisciplinary by nature'. The lead-in paragraph to this statement reads:

First, there is no such thing as purely monodisciplinary doctrinal analysis. To study and interpret legal materials, researchers have to rely on history and linguistics. To deal with apparent contradictions, they need to apply logic, argumentation theory, and philosophy. To understand the purpose of legal regulations, they must understand the society in which law is embedded, and the human behaviour it attempts to regulate. This means that they need to incorporate behavioural disciplines such as economics, sociology, and psychology. Finally, as Dworkin has convincingly argued, in order to construct legal doctrine in its best light, legal analysis must incorporate moral and political philosophy.

My difficulty with this argument is that it uses the fact that doctrinal researchers 'rely' on, 'apply', 'understand', and 'incorporate' knowledge from other disciplines as conclusive support for the proposition that doctrinal analysis cannot be 'purely mono-disciplinary'. As indicated, that way of proceeding ignores the alternative understanding that, in drawing on other disciplines, doctrinal researchers are not conducting interdisciplinary research, but simply deploying the accepted reasoning techniques of the legal tradition in which they are working. On one famous view, after all, law's characteristic mode is to be 'cognitively open' to other social systems but 'normatively closed'.7 In just the same way,

7. N. Luhmann, Law as a Social System trans. K.A. Ziegert, ed. F. Kastner, R. Nobles, D. Schiff \& R. Ziegert (2004) doctrinal research may draw on knowledge produced by other disciplines, and even mimic their methods, without necessarily becoming interdisciplinary. If a doctrinal researcher makes a philosophical point about the meaning of a legal concept, for example, that is not necessarily interdisciplinary research. Its status as such depends on whether an argument like that can be made according to conventionally accepted reasoning techniques in the legal tradition concerned. If it can, such research is 'purely mono-disciplinary' in the sense that it remains within the confines of acceptable doctrinal argument in that legal tradition.

Underlying my difficulty with the editors' approach, it should by now be clear, is a particular understanding of the nature of doctrinal research as an academic discipline. As I have argued at greater length elsewhere, ${ }^{8}$ the crucial defining feature of doctrinal research is that it is offered as a participant act in a particular legal system. ${ }^{9}$ Unlike other academic disciplines, doctrinal researchers are not primarily addressing a scholarly community, but a legal-professional community engaged in a joint enterprise of constructing legal doctrine. Their function in that community is not the same, to be sure, as legislatures and judges. They are systematisers and refiners, not primary producers. That entails certain differences of perspective. Legal academics, for example, have greater freedom to explore the connections between cases and the impact of new statutory frameworks on the legal system as a whole. They also have a role as change agents in the legal system, using their greater distance from practice and the time they have for reflection to make suggestions about how the law might be improved. Even when criticising the way a particular case has been decided or a statute's attempts to reform the law, however, doctrinal researchers need to present their arguments in a form that legal practitioners find intelligible and consonant with accepted reasoning techniques. This understanding of doctrinal research as a participant act in a particular legal system means that the methodological standards for doctrinal research are set by the legal tradition in which the researcher is working.Unlike other academic disciplines, doctrinal research has no transnational standards or claim to universal applicability. Rather, what constitutes sound research is determined by highly localised standards peculiar to the legal tradition, and even the particular area of law, ${ }^{10,11}$ in which the researcher is working. Provided the doctrinal researcher respects those standards, the fact that his or her research may not be convincing

8. Theunis Roux, 'Judging the Quality of Legal Research: A Qualified Response to the Demand for Greater Methodological Rigour' (2014) 24 Legal Education Review 173

9. See C. McCrudden, 'Legal Research and the Social Sciences' (2006) 122 Law Quarterly Review 632, 633 ('traditional legal analysis adopts an "internal" approach', which involves 'the analysis of legal rules and principles taking the perspective of an insider in the system').

10. For a similar view, see D. Nelken, 'Why Must Legal Ideas Be Interpreted Sociologically? Roger Cotterrell and the Vocation of Sociology of Law', in R. Nobles and D. Schiff (eds.), Law, Society and Community (2014) 23 , at 28 .

11. See Roux, above n. 8 
to a researcher from another discipline is irrelevant. At least, the answer to any such criticism is the same answer that an economist would give to criticism from an historian, or a political theorist to criticism from an empirical social scientist: that is not the way we do things here.

It follows further that, if the legal tradition in which the doctrinal researcher is working supports a particular way of using knowledge from another discipline, it is open to the doctrinal researcher to adopt that method, however incompetent this may seem to scholars within that other discipline. Equally, if a doctrinal researcher can show that the way the legal tradition in which he or she is working uses knowledge from other disciplines is deficient, measured by that tradition's standards, this should be pointed out. But that would again be with a view to participating in the construction of legal doctrine in a particular legal system. Doctrinal researchers' primary fidelity, in other words, is to the standards, including the internal values and purposes, of the legal tradition in which they are working, not to the methodological standards of the disciplines on which they may from time to time draw.

Of course, the internal values and purposes of a legal tradition usually include a commitment to improving the way justice is administered (or 'making the law better', as it is sometimes put). To that extent, it is open to the doctrinal researcher to argue that the values and purposes of his or her legal tradition would be better served if knowledge from another discipline were used more rigorously. ${ }^{12}$ Even in this case, however, such an argument would not entail a holus bolus subordination of the standards of the legal tradition in which the doctrinal researcher was working to the standards of the other discipline. Only so much of the other discipline's standards as were necessary to promote the particular legal tradition's values and purposes would need to be respected. The aim of this type of doctrinal research, in other words, would not be interdisciplinary synthesis or even dialogue, but one-way borrowing with a view to the improvement of legal doctrine.

This understanding of doctrinal research entails certain consequences for law as an academic discipline (my second axe). Most importantly, the diversification of legal research over the last 40 years should not be understood as an expansion of the discipline of doctrinal research, but as an expansion of legal research - the sum total of research activities in which legal academics are engaged. But legal research in this expanded form is not an aca-

12. I leave aside here the question whether the internal values of a legal tradition are 'normatively insulated from other values' (as it was put to me by one of the anonymous reviewers of this piece). Of course, as a sociological matter, the internal norms of a legal tradition are exposed to influence by broader societal values. The point here is simply that, when it comes to assessing the soundness of a doctrinal argument, it is the internal values of the legal tradition that matter; however, much they may have been influenced in the course of their development by broader societal values. My position, in other words, is not that law is completely autonomous from other social systems but that the standards for assessing the quality of doctrinal research are internal legal standards. demic discipline according to either of the main criteria: it has no governing conceptual framework and no dominant methodology. Rather, it is a collection of disciplines and interdisciplines: doctrinal research as the core discipline, legal academics' version of socio-legal research (which combines doctrinal research with at least one other discipline), sociology of law (the monodisciplinary study of law from a sociological perspective), legal history, comparative legal research, legal philosophy (which is today typically treated as a sub-discipline of philosophy), and a variety of critical approaches (which are often concerned with doctrine, but for purposes of deconstructing rather than constructing it). In addition to this, there are the various forms of 'law and _' research in which legal academics and other scholars are engaged, much of which is mono-disciplinary research that just happens to be about law and legal institutions. $^{13}$

There is no unifying conceptual framework for all these approaches and no dominant methodology that they all employ. It is thus wrong to think of legal research in the broad as a discipline. This is what Sullivan meant, I think, when she wrote that 'the discipline of law is itself multidisciplinary, built upon if not reducible into elements of the humanities and social sciences'. ${ }^{14}$ Subject to my point about disciplines not being inherently interdisciplinary, this is an accurate description of what legal research has today become: a multidisciplinary field that is unified only by the fact that the research being conducted within it has something to do with law and legal institutions.

Within that broad multidisciplinary field, as several studies have shown, ${ }^{15}$ the most prominent form of research being conducted by legal academics in the Anglo-American world is socio-legal research. The terminology is somewhat confusing because socio-legal research is itself a multidisciplinary field that includes contributions from scholars in sociology, anthropology, political science, and so on. ${ }^{16}$ How can the typical research that legal academics do belong to a field to which they are only one of many contributors? The answer is that legal academics mostly engage in one very particular kind of socio-legal research: interdisciplinary research that combines doctrinal understandings with insights from other disciplines. Their specialisation within the broader field of socio-legal research, and the reason why they are able to do this type of research from within the legal academy, comes from the fact that they use their legal-professional training to research the interrelationship between law and society. Whereas a pure sociologist of law might be interested, say, in the way attitudes to law affect bureaucratic decision-making, a legal academic might be interested in whether a

13. See further Roux, above n. 8.

14. Sullivan, above n. 4, at 1218-1219.

15. See F. Cownie, Legal Academics: Culture and Identities (2004).

16. L.M. Friedman, 'The Law and Society Movement', 38 Stanford Law Review 763, at 773 (1986); S. Scheingold, 'A Home Away from Home: Collaborative Research Networks and Interdisciplinary Socio-Legal Scholarship', 4 Annual Review of Law and Social Science 1 (2008). 
particular administrative law rule has actually had the effect on bureaucratic decision-makers that the court developing the rule anticipated. ${ }^{17}$

This point is the segue to my third and final axe: the complaint that, if doctrinal research is understood as being inherently interdisciplinary, it is not at all certain what the difference is between doctrinal research and the particular kind of socio-legal research that legal academics do. Perhaps this is what is meant by the statement that 'we're all socio-legal now' ${ }^{18}$ But there are still legal academics (including some of my colleagues) who would strenuously deny that their research is sociolegal, and the basis for that denial has to do with the difference between doctrinal research as defined above and the legal-academic variant of socio-legal research. For the pure doctrinal researcher, reference to other disciplines always occurs on law's terms, ${ }^{19}$ with a view to improving the quality of legal doctrine. There is never any thought of subordinating the conventionally accepted reasoning techniques in the legal tradition in which they are working to the methods of another discipline. Even entering into a productive exchange between another discipline and legal doctrine is not really what their research is about. Rather, the insights and methods of the other discipline are used only in so far as, and to the extent that, they assist in shedding light on a particular doctrinal problem. ${ }^{20}$ The conception of the problem and the methods for resolving it are determined from within the discipline of doctrinal research.

The flipside of this point is that the very idea of interdisciplinarity in legal research depends on there being some distinctively legal discipline capable of entering into dialogue with other disciplines. Douglas Vick expresses this point well, I think, when he says that: 'In fact, without the strong and distinctive disciplinary basis for legal inquiries provided by doctrinalism, there would be no benchmark against which interdisciplinary experimentation could define itself. ${ }^{21}$ In the same vein, we might ask, what was all the fuss about when the field of socio-legal studies was launched? If doctrinal research is inherently interdisciplinary, why did that development initially meet with such resistance from doctrinalists, and why did socio-legal scholars breathe such a collective sigh of relief when they finally broke free of the

17. For the court developing the rule, its precise sociological effects might not have been important. Where the legal academic examines those effects and goes beyond what was doctrinally required for purposes of critiquing the rule, his or her research is properly described as sociolegal.

18. R. Collier, "“We're All Socio-Legal Now": Legal Education, Scholarship and the "Global Knowledge Economy" - Reflections on the UK Experience', 26 Sydney Law Review 503 (2004).

19. For a similar idea, see J.M. Balkin, 'Interdisciplinarity as Colonization', 53 Washington \& Lee Law Review 949, at 958 (1996) (giving an example of 'legal work' that looks interdisciplinary, but is in 'another sense' not because 'it does not stray very far from two familiar lawyerly tasks: arguing over which rule better serves public policy and finding additional citations to put in the footnotes of one's brief').

20. Cf. the idea of using other disciplines 'heuristically' in Taekema and van Klink, above n. 6.

21. D.W. Vick, 'Interdisciplinarity and the Discipline of Law', 31 Journal of Law \& Society (2004) 163, at 166 doctrinal shackles that bound them? The answer can only be that the shackles were real and that they survive to this day, although they now bind only those who choose to be bound by them.

\section{The Real Nature of the Incorporation Problem in Interdisciplinary Legal Research}

With this understanding of legal research in place, the dimensions of the incorporation problem in interdisciplinary legal research become clearer. The real problem is not what it is said to be in the editors' introduction, viz.: 'How can we translate and incorporate the various non-legal disciplines and their findings into the language of legal doctrine?' Rather, the problem is whether it is possible to do genuinely interdisciplinary research when one of the disciplines involved is doctrinal research.

Why does the editors' problem fall away? On the understanding of doctrinal research set out here, the incorporation of non-legal disciplines into doctrinal research necessarily occurs on law's terms. As practitioners of a discipline that has always used knowledge and methods from other disciplines as part of its argumentative machinery, doctrinal researchers are expert cannibalisers of material from other disciplines. ${ }^{22}$ From the point of view of legal doctrine, there is nothing particularly untoward about this. Legal doctrine's primary interest is not fidelity to the disciplines on which it draws, but fidelity to law. So the only limit on the incorporation of other disciplines from the point of view of legal doctrine is the need to ensure that other disciplines are used in a way that promotes the coherent and socially efficacious development of the law. The methodological standards that doctrinal researchers need to observe in this respect are the methodological standards of the legal tradition in which they are working.

I would place only two qualifications on this argument. First, doctrinal researchers play a particular role within the legal-professional community, which I have elsewhere described as that of a 'doctrinal clean-up team'. ${ }^{23}$ They are the systematisers and the ex post rationalisers, making coherent and smoothing out what legislatures and judges have done in the heat of parliamentary debate or case-specific law making. As part of that general clean-up role, doctrinal researchers have a heightened duty to point out instances where knowledge from other disciplines has been misapplied in ways that have produced sub-optimal results for the legal system. Thus, a doctrinal researcher might argue that Judge So-

22. I prefer the term 'cannibalising' to 'colonising' to reflect the fact that doctrinal research has no imperial ambitions. Cf. Balkin, above n. 19, at 964-67.

23. See Roux, above n. 8 
and-So relied on this particular piece of research from that discipline in support of such and such a conception of a legal norm, but the research, properly understood, does not actually support that understanding of the legal norm. In arguing thus, however, the doctrinal researcher is not primarily motivated by the desire to maintain the standards of the incorporated discipline, but by the desire to improve legal doctrine.

As to their own suggestions for reform, doctrinal researchers' status as academics within the university makes them more susceptible than judges to criticism that they have misunderstood the disciplines on which they are drawing. Where the doctrinal researcher is trying to make a contribution to those disciplines, such criticism is warranted. But where the doctrinal researcher is doing purely doctrinal research - focused only on the improvement of legal doctrine - such criticism may be misplaced. At least, the mere fact that concepts or methods from another discipline have been used in a way that researchers from that discipline think lacks rigour is not conclusive. The standard for incorporation is an internal legal standard, and doctrinal researchers are best placed to judge whether that standard has been met.

The second qualification on the argument that the incorporation of non-legal disciplines into doctrinal research necessarily occurs on law's terms is that doctrinal research, as a discipline, has an interest in continually improving its use of other disciplines. A particular legal tradition's internal standards for drawing on other disciplines are not static. Whereas, in 1950, say, a judge in Australia might have gotten away with an armchairobserver argument about the likely social effects of a legal rule, today he or she might be expected to support such an argument by reference to empirical research. This sort of phenomenon is a reflection of the evolution of legal traditions and their tendency to require ever more sophisticated reasoning techniques over time. But there is nothing in this process that means that doctrinal research is necessarily subject to the full panoply of methodological standards applied in other disciplines. ${ }^{24}$ The evolution occurs at the legal tradition's own pace, on its own terms, and doctrinal researchers are beholden to those internal, evolving standards, not to the standards of other disciplines.

As noted, doctrinal researchers' particular function within the legal system means that they may play a vanguard role in this evolutionary process. As rationalisers and systematisers, they need continually to point out to judges and legislators how they might make better use of knowledge from other disciplines. They need in this sense to push the boundaries of their discipline by challenging all participants to become more sophisticated. As educators, doctrinal researchers also have a role to play in training their students to make better use of knowledge and methods from other disciplines. Such interventions not only assist in making the students more effective practising lawyers but also enable doctrinal researchers to play the role of change agents in the legal profession. A successful piece of doctrinal research, on this view, is one that expands lawyers' horizons by showing how knowledge from other disciplines may be incorporated in a way that promotes the fairness or social effectiveness of law.

Subject to these two qualifications, the answer to the question of how other disciplines and their findings may be translated and incorporated into doctrinal research is that this must be done in the way doctrinal researchers have always done it: by following the methodological standards set by the legal-professional community of which they are a part. Since doctrinal researchers by definition have no interest in contributing to the disciplines on which they are drawing, they need not observe all of their methods to the nth degree. When faced by the criticism, as they increasingly are, that their research does not meet the standards set by other disciplines, they may legitimately respond: we are practitioners of a separate discipline, with its own standards. ${ }^{25}$ What doctrinal researchers need to get better at, of course, is explaining those standards to researchers from other disciplines. But that is a different question.

As noted, the real incorporation problem in interdisciplinary legal research is whether it is possible to do genuinely interdisciplinary research when one of the disciplines involved is doctrinal research. The essence of the problem here is that researchers who engage in the typical kind of interdisciplinary research in which legal academics are engaged - socio-legal research - are pulled in two seemingly incompatible directions. On the one hand, they need to satisfy the standards of the legal tradition in which they are working - to be faithful enough to conventionally accepted methods of legal reasoning that their doctrinal arguments carry sufficient weight to be accepted. On the other hand, they need to satisfy the standards of the scholarly literature to which they are contributing, a literature whose standards are in the nature of things policed by scholars from other disciplines. Straddling this divide is very difficult, if not impossible, for two main reasons.

The first reason is illustrated by Judge Harry Edwards's famous attack on the irrelevance of much contemporary legal-academic research. ${ }^{26}$ For many judges and legal professionals, Judge Edwards argued, legal academics' increasing interest since the 1970 s in other disciplines has taken them further and further away from their primary social function: to act as a sounding board and source of support for the legal profession. As much as legal academics may welcome the fact that their research is becoming more sophisticated in a scholarly sense, many legal professionals today think that their research is out of touch with the practical problems facing legal decision-makers. While it may be very interesting to
24. My position in this respect thus differs from that set out in $\mathrm{K}$. Burns and T. Hutchinson, "The Impact of "Empirical Facts" on Legal Scholarship and Legal Research Training', 43 The Law Teacher 153 (2009).
25. See Roux, above n. 8.

26. H.T. Edwards, 'The Growing Disjunction between Legal Education and the Legal Profession', 91 Michigan Law Review 34 (1992). 
know, for example, whether judges are influenced by their class position when deciding property rights disputes, this may be less interesting to judges than whether s 55(1)(f) of the Invented for Purposes of this Example Land Act really means that they have no discretion to issue an eviction order.

Legal academics may, of course, defend themselves against this kind of charge by confronting it head on. They can attempt to show why the problem they have identified really is a problem for the legal system, even though those involved in the practical workings of that system have not taken notice of it yet. That is part of legal academics' vanguard function, as noted earlier. But there is a point at which the pursuit of scholarly knowledge for its own sake comes into tension with the practical requirements of the legal profession. Just as much as we might want to say that the legal profession should not exclusively determine what questions legal academics research, so we might want to say that practising lawyers are under no obligation to find everything that legal academics do interesting. Practising lawyers tend to lead busier, more stressful lives than legal academics, and thus they are entitled to expect legal academics to write in a more focused, economical way if they want to make an impact. The more they respond to that legitimate expectation, however, the less credibility legal academics' work tends to have in the scholarly community. ${ }^{27}$ That is the practical dimension of the problem. The second reason why straddling the divide between legal doctrine and an external body of social scientific or humanities knowledge is difficult is a more philosophical one. It concerns the question whether it is possible to be simultaneously inside the law for purposes of contributing to legal doctrine and outside the law for purposes of contributing to another academic discipline. ${ }^{28}$ On the understanding of legal doctrine propounded here, doctrinal research is a participant act in a particular legal tradition, in which the legal researcher accepts the constraints imposed by an attitude of fidelity to law in that tradition. Importantly, this internal perspective is not just an interpretive perspective in the ordinary social science sense ${ }^{29}$ but also a participatory perspective in as much as the doctrinal researcher intends to contribute to the practice of law in the legal tradition concerned. ${ }^{30}$ How may this perspective be integrated with non-interpretive or interpretive but non-participatory perspectives? 'Can you simultaneously operate within a prac- tice', as Stanley Fish puts the point, 'and be self-consciously in touch with the conditions that enable it?"31

Fish's question suggests that the incorporation problem in interdisciplinary legal research may be no different to the incorporation problem in all interdisciplinary research: one of the disciplines involved is always going to come out on top and that is typically going to be the discipline in which the researcher was first trained. This is what one might call the 'spectacles' view of the problem, where training in a particular discipline is understood as a form of socialisation that is very hard to shake. Even if researchers take two undergraduate degrees, say, or do specialised postgraduate courses in the methods of another discipline, the discipline that gets to their untrained mind first is going to be the discipline through which they see the world, and through which they ineluctably translate the insights of the second discipline, even as they attempt to conduct their research in a scrupulously even-handed way.

If there is a special dimension to this problem in the case of interdisciplinary legal research, it is that the two communities between which the legal researcher is trying to move are very different: the one a mixed legal-professional/academic community and the other a pure academic community. This may entail certain added difficulties. The knowledge system to which legal researchers are contributing, for one, is not the privately produced, corrigible work product of a purely academic discipline, but the state-sanctioned legal system, with its corpus of authoritative norms and its conventionally accepted ways of working with those norms. The practical dimension to this, as we have seen, is the problem of moving between two very different audiences, each with its own expectations and standards. The philosophical dimension is that the two audiences are engaged in very different sorts of practices: one that is about the construction of legal doctrine and another that is about the accumulation of scholarly knowledge.

Rather than trying to contribute to the philosophy of interdisciplinarity (for which I am not equipped), the rest of this paper tries to illustrate the practical and philosophical sides of the incorporation problem as I have experienced them in my own research. Given my insistence on respecting the disciplinary boundaries of doctrinal research, it may come as a surprise to learn that my own research is interdisciplinary. As I hope to show, however, successful interdisciplinarity is not about ignoring or transgressing disciplinary boundaries, but about researching across two or more disciplines while remaining true to their methods and purposes.
27. This tension is experienced in Australia in the lower status accorded to 'practitioner journals'. Under the new Research Performance Measure about to be introduced at UNSW Australia, for example, legal academics who write for those journals will receive fewer points than those who publish in highly regarded international journals.

28. See B.Z. Tamanaha, 'The Internal/External Distinction and the Notion of a "Practice" in Legal Theory and Sociolegal Studies', 30 Law \& Society Review 163 (1996)

29. M.S. Moore, 'The Interpretive Turn in Modern Theory: A Turn for the Worse?', 41 Stanford Law Review 871 (1989).

30. See R.M. Dworkin, Law's Empire (1986) 14.
31. S. Fish, There's No Such Thing as Free Speech (and It's A Good Thing Too) (1994). 


\section{Illustration from My Own Research}

My main research interest for the last 15 years or so has been the politics of judicial review. Typically, this research interest has been thought to be a research specialisation in comparative politics, which is itself a specialisation in political science. Having had no formal training in political science, however, I necessarily had to come at the politics of judicial review from an interdisciplinary perspective. In particular, my research is being conducted at the interface of comparative constitutional law (a rapidly growing international research field in which legal academics from a number of different countries have been participating ${ }^{32}$ ) and comparative judicial politics (the specialisation within comparative politics that looks at the role of constitutional courts in national political systems ${ }^{33}$ ).

Constitutional lawyers and political scientists have, of course, long been engaged in an interdisciplinary dialogue, particularly in the United States, where the study of judicial politics grew out of the American legal realist call for a science of judicial decision-making. ${ }^{34}$ Despite that starting point, political scientists initially went their own way, their methods heavily influenced by the behaviourist movement in the social sciences. ${ }^{35}$ Behaviourists took an entirely external perspective on judicial decision-making, using quantitative methods to discern causal relationships between, say, the party of the appointing President and the outcome of judicial decisions in ideological terms. This approach modelled law in a way that was so radically alien to the legal-academic perspective that academic lawyers mostly ignored it. It was only from the mid-1980s or so that legal academics started to pay more attention to political science accounts of judicial decision making. This was facilitated, first, by the proliferation of rational choice scholarship, which permeated both the legal academy and political science departments, and then by the rise of historical institutionalism in political science, which conceives of law in a way that most legal academics recognise - as a relatively autonomous social system with its own internal values, traditions, and thought processes. ${ }^{36}$ Within political science, the historical institutionalist perspective has influenced judicial behaviourists, who have begun to model law in more sophisticated

32. The field has its own specialist journal (the International Journal of Constitutional Law) and scientific body (the International Association of Constitutional Law).

33. For a useful introduction, see Part III of K.E. Whittington, R.D. Kelemen \& G.A. Caldeira (eds.), The Oxford Handbook of Law and Politics (2010).

34. See B.Z. Tamanaha, Beyond the Formalist-Realist Divide: The Role of Politics in Judging (2009).

35. Ibid., at 112-15.

36. See C.W. Clayton and H. Gillman (eds.), Supreme Court Decision-Making: New Institutionalist Approaches (1999). ways. ${ }^{37}$ At the same time, legal academics have started to do their own quantitative research on judging. ${ }^{38}$ All of this has brought political scientists and academic lawyers in the United States much closer together than they have been for some time. ${ }^{39}$

Beneath the apparently calm surface, however, there is still quite a lot of tension between the two sets of scholars. Lee Epstein and Gary King's brutal attack on the empirical methods used in American law reviews is the most famous instance of this, ${ }^{40}$ but there have been other interventions as well. ${ }^{41}$ In my own particular area of specialisation, Ran Hirschl has been particularly hardhitting in his criticisms of comparative constitutional lawyers, dismissing much of their work as being of little scholarly value. ${ }^{42}$ As with Epstein and King's more general critique, Hirschl's comments focus on legal academics' alleged lack of comprehension of the 'rules of inference' - of how to move from empirical observations about particular cases to more generalised propositions of social science. Even allowing for the fact that not all social scientists would necessarily see things the same way, these criticisms have been bracing, to say the least. There is also reason to think, however, that political scientists do not always properly understand what is at stake for legal academics when they undertake crosscountry comparisons. The fact that a particular legal tradition, for example, may authorise reference to foreign law in a particular way, is a point often missed.

In my own research, I have tried to integrate my understanding of constitutional law doctrine in the two jurisdictions in which I have worked with the conceptual frameworks and methods of comparative judicial politics. My first proper attempt at doing so was published in my 2013 book on the South African Constitutional Court (CCSA).$^{43}$ Chapter 1 of that book sets out what I argued was a necessarily interdisciplinary research question: how it came about that the CCSA, in the first 10 years of its existence, had been successful in two very different senses - a political science sense, which had to do with its effectiveness as a veto player in South African politics, and a legal-doctrinal sense, which had to do with its internationally admired, principled interpretation of the 1993 and 1996 South African Consti-

37. See B.L. Bartels, 'The Constraining Capacity of Legal Doctrine on the U.S. Supreme Court', 103 American Political Science Review 474 (2009); M.A. Bailey and F. Maltzman, The Constrained Court: Law, Politics, and the Decisions Justices Make (2011).

38. See, for example, C.R. Sunstein, D. Schkade, L.M. Ellman \& A. Sawicki, Are Judges Political? An Empirical Analysis of the Federal Judiciary (2006)

39. There are chairs in Law and Political Science at Yale, Duke, and Chicago, for example.

40. L. Epstein and G. King, 'The Rules of Inference', 69 University of Chicago Law Review 1 (2002).

41. See also G.N. Rosenberg, 'Across the Great Divide (Between Law and Political Science)', 3 2d Green Bag 267 (2000).

42. See R. Hirschl, 'On the Blurred Methodological Matrix of Comparative Constitutional Law', in S. Choudhry (ed.), The Migration of Constitutional Ideas (2007) 39 and R. Hirschl, 'Editorial', 11 International Journal of Constitutional Law 1 (2013).

43. Theunis Roux, The Politics of Principle - The First South African Constitutional Court, 1995-2005 (2013). 
tutions. $^{44}$ While definitive of mature constitutional courts, I argued, simultaneous success on these two fronts is something that is very rarely achieved by a constitutional court in a new democracy and something which neither a purely doctrinal understanding of the Court's decisions nor comparative judicial politics on its own could properly explain. In Chapter 2 of the book, I accordingly proceeded to develop an interdisciplinary conceptual framework for addressing my research question. The main argument of that chapter was that some mediating concept was required to bring the two disciplines on which I was relying into dialogue with each other. In particular, I suggested that the idea of 'constraint', which features in both disciplines albeit in different guises, could be used as a basis for examining how constitutional courts negotiate the competing demands of law and politics.

The rest of the book applied that framework to analyse the CCSA's decision-making record, in the process blending doctrinal analysis with insights from the comparative judicial politics literature. For example, in Chapter 9, I tried to show how the CCSA's case law enforcing political rights was perhaps the most disappointing aspect of its record in purely doctrinal terms and that this could be explained by the difficulty the judges experienced in adapting their decisions in that area of law to the cooperative working relationship they were trying to forge with the ruling African National Congress. To make this kind of argument, I coined various terms to emphasise the interdisciplinary approach I was using, including 'adjudicative strategy' (to capture the way in which a court in a developed legal tradition like the South African must establish its independence in and through the constraints imposed by law), 'micropolitics' (to capture the local political circumstances surrounding a case that might give the court greater freedom to mediate the competing demands of law and politics), and 'legal-cultural lag-effect' (to capture the way in which the received legal tradition exerts an inertial effect on changes in reasoning style apparently required by a new, rights-based Constitution).

I do not as yet know whether my book has succeeded in laying the basis for a new interdisciplinary conversation. Two reviews have thus far been published, but neither really focuses on the interdisciplinary aspects of my work. I do know for certain, however, that my book did not impress at least one judge on the CCSA who wrote to me to complain about the absence of a table of cases. I had in fact included such a table in the draft manuscript submitted to the publisher, but then took it out, partly because the cases were already referenced in the index, but partly also to signal that my book was not a traditional doctrinal commentary on the work of the CCSA that could be used in legal argument and judgment writing. That signalling attempt obviously failed, suggesting that there is still work to do, in South Africa at least, in convincing practising lawyers that a book about judicial decision-making might have a broader scholarly purpose

44. Ibid., at 15-71. than simply assisting the legal profession to do its job better.

Perhaps I should also take this incident as an indication that, of the two audiences I was trying to address in the book - the South African legal-professional community and the international comparative constitutional law/ judicial politics community - I might have ended up catering more to the second. Certainly, no advocate arguing a case before the CCSA or judge writing an opinion for the Court will find anything particularly helpful in my book of a purely doctrinal nature. It is not written for that purpose. Rather, I was trying to inject into the local South African conversation a more realistic appreciation of the political constraints under which the CCSA was operating. To the extent that I dealt with doctrine, my purpose was to show how the judges were able to fashion review standards that supported a sustainable institutional role for the Court. In presenting the development of legal doctrine in this way, I argued that the political context in which the Court was working influenced its decisions - that it deliberately chose doctrines that enhanced its capacity to continue independently enforcing the Constitution over the long run. In so doing, I wanted to reappropriate for liberal legalism a sense of law's malleability in the service of political ideals that has for too long been the preserve of critical legal theory. The proposition that judges' sense of their court's institutional vulnerability might influence their decisions is, however, anathema to South African constitutional law's conception of itself as separate from politics. As soon as I made that argument, therefore, I was no longer participating in the construction of legal doctrine but viewing legal doctrine from the external perspective of political science. I had my cake, but I could not eat it.

\section{Conclusion}

What does my experience have to teach about the difficulties of doing interdisciplinary legal research? The first lesson, I think, is that, however hard one tries to straddle the divide between doctrinal research and another discipline, one does ultimately need to pick an audience. As much as one's skills as a trained lawyer help one to understand the internal demands of the law, there comes a point when what one is researching ceases to be of much interest to legal practitioners and has broader scholarly significance only. In this respect, academic lawyers are in a peculiar situation. Their competitive advantage is that they know better than the average social scientist what the internal demands of the law are on the judges deciding the cases they are examining. Their competitive disadvantage, however, is that they tend not to be terribly well versed in the methodologies required to support a sophisticated social science research project.

The philosophical concern mentioned earlier is also borne out, albeit in a somewhat unexpected way. On the 
one hand, my experience suggests that Stanley Fish was right to argue that it is virtually impossible to participate in two disciplinary practices at the same time; one practice is invariably going to dominate the other. On the other hand, in my case at least, it has not been my primary training as a lawyer that has come to dominate but my aspirations to contribute to the political science literature on judicial decision-making. There may be idiosyncratic reasons for this. The fact that I migrated from South Africa to Australia in 2009 means that since then I have been working outside my primary legal-professional environment. Like others who have left their home jurisdictions, ${ }^{45}$ this has given me an acute sense of the differences between countries in legal-cultural terms, which is how law now mainly figures as an explanatory variable in my work. Had I not left South Africa that might have not been the case, and thus Fish's argument may still be valid as a general rule.

Still, I think my experience is generalisable to the extent that it suggests that interdisciplinary research is hard to do, at least in a sustained way. The problem is not, as I have been stressing, that it is difficult to incorporate knowledge from other disciplines into doctrinal research. Doctrinal researchers do that all of the time, using the methods that have developed in their legal tradition for doing this. Rather, the problem is that it is very difficult to sustain a long-term research project that is genuinely interdisciplinary in the sense that it: (i) is driven by a research question that no single discipline on its own can adequately answer and (ii) combines doctrinal research with at least one other discipline in a more or less even-handed way. A true synthesis or complete integration of disciplines, of course, might be the ultimate goal. In my case, that would mean the integration of comparative judicial politics and comparative constitutional law in a way that took both politics and law seriously as separate forms of constraint on judicial decision-making. Even, then, however, the question would be whether the research being conducted was still interdisciplinary or whether it was contributing to the formation of a new discipline. 